Blood collected from cardiac puncture of the aborted fetus showed no haemoglobin A on isoelectrofocusing and cellulose acetate electrophoresis. Haemoglobin $\mathrm{F}$ was the only detectable haemoglobin.

\section{Discussion}

Fetal blood sampling for globin chain synthesis has been the main method of diagnosing $\beta$ thalassaemia prenatally. It is performed in the midtrimester and carries a fetal mortality of $5.6 \% .^{3}$ Analysis of fetal DNA is safer, and earlier diagnosis can be achieved if DNA is obtained from chorionic villi rather than amniotic fluid cells. ${ }^{4}$ However, $\beta$ thalassaemia is heterogenous and usually the abnormal DNA cannot be distinguished by hybridisation with total globin probe. When the molecular defects for $\beta$ thalassaemia in a particular population are defined oligonucleotide probes may be used to detect specific nucleotide mutations. ${ }^{5}$

For the present, linkage analysis is a feasible approach. We have shown that in the local Chinese population in Hong Kong there is pronounced linkage disequilibrium for BamH I polymorphism in normal subjects compared with those with $\beta$ thalassaemia, such that this single site may be used for prenatal diagnosis in $29 \%$ of the pregnancies at risk. For the remaining cases analysis of multiple restriction polymorphic sites around the $\beta$ gene cluster might show the appropriate site for prenatal diagnosis. ${ }^{2}$

We thank Dr T Maniatis for the $\beta$ globin probe; the Hong Kong University Research Fund and the Medical Faculty Research Fund for financial support; Dr Y M Cheung for help in collecting the samples; and Mr A Wong, Mr C S Kwan, and Mr C K Lai for skilful technical help.

\section{References}

1 Kan YW, Lee KY, Furbetta M, et al. Polymorphism of DNA sequence in the $\beta$-globin gene region. Application to prenatal diagnosis of $\beta^{\circ}$ thalassaemia in

2 Kazazian HH Jr, Phillips JA, Boehm CD, et al. Prenatal diagnosis of $\beta$-thalassaemias by amniocentesis: linkage analysis using multiple polymorphic restriction endonuclease sites. Blood 1980;56:926-30

3 Alter BP. Prenatal diagnosis of hemoglobinopathies: worldwide experience. Birth Defects 1982;18:263-74.

4 Old JM, Ward RHT, Pctrou M, et al. First-trimester fetal diagnosis for haemoglobinopathies: three cases. Lancet 1982; ii:1413-6.

Pirastu M, Kan YW, Cao A, et al. Prenatal diagnosis of $\beta$-thalassaemia. Detection of a single nucleotide mutation in DNA. $N$ Engl $\mathcal{F}$ Med 1983;309:284-7.

(Accepted 26 fuly 1984)

○

\title{
Correlation between serum ionised calcium and serum albumin concentrations in two hospital populations
}

\author{
S J BUTLER, R B PAYNE, I R GUNN, J BURNS, C R PATERSON
}

\begin{abstract}
One quarter of 172 patients from two hospitals with no obvious disturbances of calcium homoeostasis and with total serum calcium concentrations that were normal after adjustment for albumin concentration had low serum ionised calcium concentrations. The low values were not due to changes in $\mathrm{pH}$ but were associated with hypoalbuminaemia. Significant positive regressions of ionised calcium on albumin concentration were observed in patients from both hospitals and also in 48 healthy laboratory staff. Because the regressions did not differ between patients and healthy subjects the low ionised calcium values associated with hypoalbuminaemia are unlikely to have been of pathological importance.

These findings indicate that interpreting serum ionised calcium concentrations in patients with a reduced serum albumin concentration on the basis of a reference range determined in subjects with a normal serum albumin concentration may be clinically misleading.
\end{abstract}

\footnotetext{
Department of Chemical Pathology, St James's University Hospital, Leeds LS9 7TF

S J BUTLER, PHD, MSC, biochemist

R B PAYNE, MD, FRCPATH, consultant chemical pathologist

Department of Biochemical Medicine, Ninewells Hospital, Dundee DD1 9SY

I R GUNN, MB, registrar

J BURNS, MSC, FIMLS, medical laboratory scientific officer

C R PATERSON, DM, FRCPATH, senior lecturer

Correspondence to: Dr R B Payne.
}

\section{Introduction}

Direct measurement of the ionised fraction of calcium in serum is generally accepted as the best way of detecting disturbances of calcium homoeostasis in patients with abnormal serum proteins. In vitro experiments, however, have raised the possibility that protein concentration itself can interfere with the measurement of ionised calcium, ${ }^{12}$ although this interpretation of the data has been disputed. ${ }^{3}$ We report here independent studies from St James's University Hospital, Leeds, and Ninewells Hospital, Dundee, investigating the relation between ionised calcium and albumin concentrations in hospital patients and laboratory staff.

\section{Subjects and methods}

Patients and normal controls-Seventy eight inpatients and 33 outpatients were studied in Leeds, and 61 inpatients in Dundee. They were adults of both sexes with no obvious clinical disturbance of calcium homoeostasis or acid base balance. We excluded patients in intensive care units, those with the nephrotic syndrome, those receiving haemodialysis, and those with serum total calcium concentrations adjusted for albumin concentration that fell outside the normal range $(2 \cdot 20-2 \cdot 60 \mathrm{mmol} / 1(8 \cdot 8-10 \cdot 4 \mathrm{mg} / 100 \mathrm{ml}))$. The adjustment for albumin concentration used in Leeds was total calcium ( $\mathrm{mmol} / \mathrm{l})+0.025$ $(40-$ albumin $(\mathrm{g} / \mathrm{l})),{ }^{4}$ and that used in Dundee was total calcium $(\mathrm{mmol} / \mathrm{l})+0.023(40$ - albumin $(\mathrm{g} / \mathrm{l}))$. Data were also obtained from healthy laboratory staff volunteers (48 in Leeds and 34 in Dundee).

Methods-In both hospitals serum albumin concentration was measured by a dye binding technique using bromocresol green and Technicon continuous flow automated equipment. In Leeds serum ionised calcium concentration was measured with a Nova 2 analyser and $\mathrm{pH}$ with an IL 313 blood gas analyser within two hours after collection of blood into a Vacutainer tube. In Dundee plasma containing $15 \mathrm{IU}$ lithium heparin $/ \mathrm{ml}$ was analysed for ionised calcium and 
pH with a Radiometer ICA1, precautions having been taken to minimise $\mathrm{pH}$ changes. The analytical standard deviations averaged $0.8 \mathrm{~g} / 1$ at $40 \mathrm{~g} / 1$ for albumin and $0.02 \mathrm{mmol} / 1(0.08 \mathrm{mg} / 100 \mathrm{ml})$ at $1.22 \mathrm{mmol} / \mathrm{l}(4.9 \mathrm{mg} / 100 \mathrm{ml})$ for ionised calcium in both hospitals. Data were analysed by the method of least squares and by the linear regression method of Deming. ${ }^{5}{ }^{6}$ Ionised calcium concentrations at $\mathrm{pH}$ 7.40 were calculated from the equation built into the software of the ICA1 analyser. ${ }^{7}$

\section{Results}

The table shows the limits that included $95 \%$ of the measured values of albumin concentration, $\mathrm{pH}$, and ionised calcium concentration and of ionised calcium concentration adjusted for $\mathrm{pH}$ in the two groups of hospital patients and healthy laboratory staff. Values below the lower $95 \%$ limit for ionised calcium in laboratory staff $(1.15 \mathrm{mmol} / \mathrm{l}$ $(4.6 \mathrm{mg} / 100 \mathrm{ml}))$ were present in $29(26.1 \%)$ of the patients in Leeds and $16(26 \cdot 2 \%)$ of the patients in Dundee.

Observed 95\% limits of measured and calculated values

\begin{tabular}{|c|c|c|c|c|}
\hline & \multicolumn{2}{|c|}{ Leeds } & \multicolumn{2}{|c|}{ Dundee } \\
\hline & $\begin{array}{l}\text { Patients } \\
(\mathrm{n}=111)\end{array}$ & $\begin{array}{l}\text { Laboratory staff } \\
\quad(n=48)\end{array}$ & $\begin{array}{l}\text { Patients } \\
(n=61)\end{array}$ & $\begin{array}{l}\text { Laboratory staff } \\
\quad(n=34)\end{array}$ \\
\hline \multirow{3}{*}{$\begin{array}{l}\text { Albumin }(\mathrm{g} / \mathrm{l}) \\
\text { Venous } \mathrm{pH} \\
\text { Measured ionised } \\
\text { calcium }(\mathrm{mmol} / \mathrm{l}) \\
\text { Ionised calcium } \\
\text { adjusted for } \mathrm{pH} \\
\text { (mmol/l) }\end{array}$} & $\begin{array}{c}24-48 \\
7 \cdot 33-7 \cdot 48\end{array}$ & $\begin{array}{c}39-50 \\
7 \cdot 35-7 \cdot 42\end{array}$ & $\begin{array}{c}26-42 \\
7 \cdot 32-7 \cdot 51\end{array}$ & $\begin{array}{l}\text { Not measured } \\
7 \cdot 36-7 \cdot 44\end{array}$ \\
\hline & $1 \cdot 02-1 \cdot 26$ & $1 \cdot 15-1 \cdot 26$ & $1 \cdot 04-1 \cdot 26$ & $1 \cdot 15-1 \cdot 27$ \\
\hline & $1 \cdot 01-1 \cdot 26$ & $1 \cdot 14-1 \cdot 24$ & $1 \cdot 07-1 \cdot 25$ & $1 \cdot 15-1 \cdot 27$ \\
\hline
\end{tabular}

Conversion: SI to traditional units-Ionised calcium: $1 \mathrm{mmol} / 1 \approx 4 \mathrm{mg} / 100 \mathrm{ml}$

Positive correlations between ionised calcium and albumin concentrations were found in both groups of patients (Leeds: $r=0.467$, $p<0.001$; Dundee: $r=0.553, p<0.001)$ and in laboratory staff $(r=$ $0.557, p<0.005)$. Significant regressions of ionised calcium on albumin concentrations were present in the 32 female and 16 male laboratory staff when analysed separately (women: $\mathrm{r}=0.534, \mathrm{p}<0.002$; men: $r=0.533, p<0.05$ ), and the slopes did not differ significantly.

Ionised calcium concentration correlated with hydrogen ion concentration in both groups of patients (Leeds: $r=0.301, p<0.05$; Dundee: $r=0.554, p<0.001)$ but not in the laboratory staff $(r=0.232$, $p>0 \cdot 1$ ). There was no correlation between hydrogen ion and albumin concentrations in the Leeds patients or the laboratory staff, but there was a weak positive correlation in the Dundee patients $(r=0.253$, $p<0 \cdot 05$ ). After adjustment of each ionised calcium concentration for $\mathrm{pH}$ there was no residual correlation of ionised calcium with hydrogen ion concentration in any group (Leeds: $r=0.055, p=0.58$; Dundee: $r=0.009, p=0.94$; laboratory staff: $r=-0.119, p=0.57$ ). The proportion of patients with low ionised calcium concentrations, however, changed little (Leeds $33.1 \%$; Dundee $24.6 \%$ ), and significant correlations of ionised calcium concentration adjusted for $\mathrm{pH}$ with albumin concentration remained in all three groups (Leeds: $\mathrm{r}=0.425, \mathrm{p}<0.001$; Dundee: $\mathrm{r}=0.477, \mathrm{p}<0.001$; laboratory staff: $\mathrm{r}=0.577, \mathrm{p}<0.001$ ). The Deming regression equations were:

$$
\text { ionised calcium adjusted for } \mathrm{pH}=\left\{\begin{array}{c}
0.00465 \text { albumin }+0.982 \text { (Leeds) } \\
0.00537 \text { albumin }+0.990 \\
\text { (Dundee) } \\
0.00663 \text { albumin }+0.896 \\
\text { (laboratory staff) }
\end{array}\right.
$$

The standard errors of the slopes were $0 \cdot 00084,0 \cdot 00114$, and 0.00124 $\mathrm{mmol} / \mathrm{g}$ respectively. The figure shows the data for Dundee.

The slopes and intercepts of ionised calcium on albumin concentrations and of ionised calcium adjusted for $\mathrm{pH}$ on albumin concentrations did not differ significantly between the three groups of subjects. None of the correlation coefficients differed significantly.

\section{Discussion}

We were surprised that about one quarter of patients with no obvious clinical disturbance of calcium homoeostasis or acid base balance and with normal total calcium concentrations after adjustment for albumin concentration had measured ionised calcium concentrations below the limit of normal and that there were significant positive correlations between ionised calcium and albumin concentrations in both hospital populations studied and also in healthy laboratory staff. None of the slopes or intercepts before or after the ionised calcium concentration was adjusted for $\mathrm{pH}$ differed significantly between the three groups. This finding is the more striking because the studies were carried out independently in Leeds and Dundee using different methods of collecting and storing samples and different apparatus for measuring ionised calcium concentration and $\mathrm{pH}$.

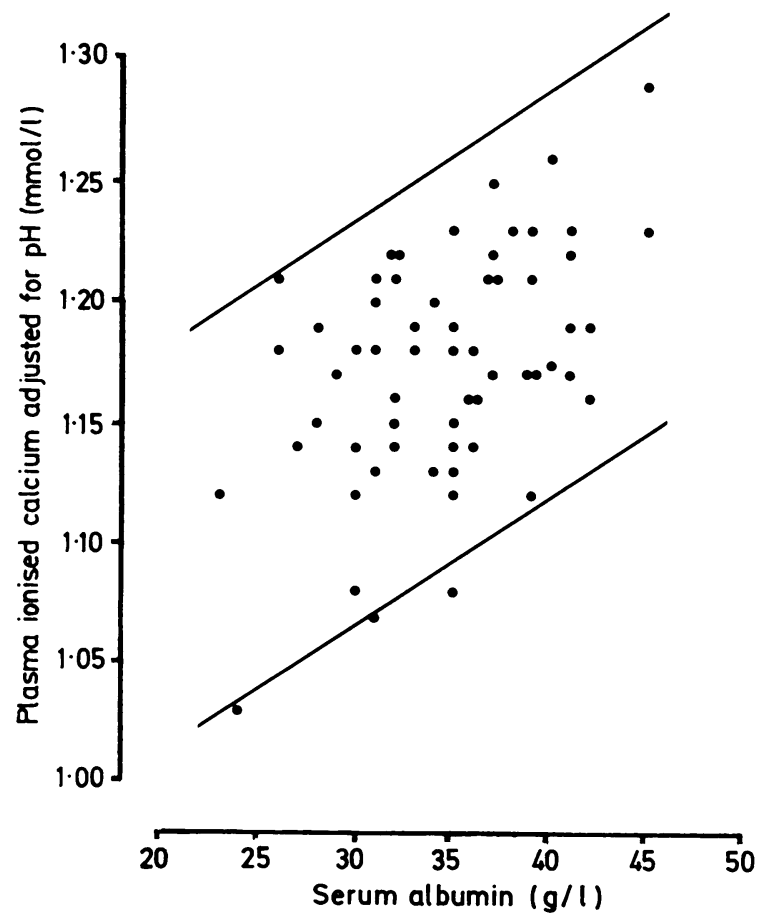

Relation between plasma ionised calcium concentration adjusted for $\mathrm{pH}$ and serum albumin concentration in 61 inpatients in Dundee with no obvious clinical disturbance of calcium homoeostasis or acid base balance. The continuous lines are the $95 \%$ confidence limits of the Deming regression equation in the y direction. ${ }^{6}$

Conversion: SI to traditional units-Ionised calcium: $1 \mathrm{mmol} / 1 \approx 4 \mathrm{mg}$ | $100 \mathrm{ml}$.

The low ionised calcium values cannot be accounted for by an association between lowered serum albumin and hydrogen ion concentrations because there was no correlation between these variables in either the Leeds patients or the laboratory staff and only a weak positive association in the Dundee patients. Neither can the correlation of ionised calcium adjusted for $\mathrm{pH}$ with albumin be accounted for by a bias, dependent on albumin, in the adjustment. Such a bias would result in a positive correlation only if the patients were predominantly acidotic. This was not the case (table).

One possible explanation of our findings is that among hospital patients there is an exceptionally high prevalence of malnutrition causing both low albumin concentrations and hypocalcaemia due to vitamin $\mathrm{D}$ deficiency. This and other pathological mechanisms, however, seem unlikely as we found a similar correlation among our healthy laboratory staff.

The positive correlation between measured ionised calcium and albumin concentrations reported previously in dialysis and ultrafiltration experiments in vitro might be due to a positive interference by protein with the instruments used to measure ionised calcium or to Donnan distribution effects. ${ }^{1-3}$ An interference by protein would clearly explain our findings in the patients. If homoeostatic mechanisms respond to extravascular ionised calcium an in vivo Donnan effect across vascular membranes would provide an alternative explanation.

Several findings reported previously may well be explained by 
a reduction in measured ionised calcium concentration as plasma albumin concentration falls. These include decreased ionised calcium concentrations in normal people over $80^{8}$ and decreasing ionised calcium concentrations in mothers during the course of normal pregnancy. ${ }^{9}$ In a study of postmenopausal women being treated with oestrogen the fall in albumin concentration that followed treatment may have contributed to the associated fall in ionised calcium concentration ${ }^{10}$; and the lower albumin concentrations observed in diabetics treated with insulin, in whom serum parathyroid hormone concentrations were normal, may have contributed to their lower ionised calcium concentrations. ${ }^{11}$

Ionised calcium concentrations are higher in ambulant than in supine subjects, ${ }^{12}$ and Lazar et al found that the increase on standing paralleled the increase in plasma oncotic pressure (largely due to albumin). ${ }^{13}$ The concept of an adjustment of total calcium for albumin seems to have come full circle with the suggestion by these workers that measured values of ionised calcium should be "normalised" for oncotic pressure.

In patients we found that a mean difference in albumin concentration of $10 \mathrm{~g} / 1$ was associated with a mean difference in measured ionised calcium of about $0.05 \mathrm{mmol} / 1(0.2 \mathrm{mg} / 100 \mathrm{ml})$, which is more than one third of the normal reference range. Whatever the correct explanation of the association, the similar regressions of ionised calcium on albumin concentrations in patients and healthy subjects imply that the low ionised calcium values in hypoalbuminaemia are unlikely to be of pathological importance. We suggest that the interpretation of serum ionised calcium concentration in patients with hypoalbuminaemia on the basis of a reference range determined in subjects with a normal serum albumin concentration may be clinically mis- leading: hypocalcaemia may be overdiagnosed and hypercalcaemia underdiagnosed.

The Leeds study formed part of the work for an MSc in the University of Leeds. The work in Dundee was supported by a grant from the Scottish Home and Health Department.

\section{References}

1 Payne RB. Clinically significant effect of protein concentration on ion-selective electrode measurements of ionised calcium. Ann Clin Biochem 1982;19:233-7.

2 Buckley BM, Smith SCH, Heath DA, Bold AM. Clinical studies on ionized calcium using the R
(suppl 165):87-92.

3 Thode J, Fogh-Andersen N, Sigaard-Andersen M, Sigaard-Andersen $O$. Ann Clin Biochem 1983;20:271-3.

4 Payne RB, Little AJ, Williams RB, Milner JR. Interpretation of serum calcium in patients with abnormal plasma proteins. Br Med f 1973 ;iv:643-6.

5 Deming WE Statistical adjustment of data. New York: John Wiley, 1943:184

6 Cornbleet PJ, Gochman N. Incorrect least-squares regression coefficients in ornbleet PJ, Gochman N. Incorrect least-squares reg
method-comparison analysis. Clin Chem 1979;25:432-8.

7 Fogh-Andersen N. Ionized calcium analyzer with a built-in pH correction. Clin Chem 1981;27:1264-7.

8 Lingärde F. Potentiometric determination of serum ionized calcium in a normal Lingärde F. Potentiometric determination of serum ion
human population. Clin Chim Acta 1972;40:477-84.

Pitkin RM, Gebhardt MP. Serum calcium concentrations in human pregnancy. Pitkin RM, Gebhardt MP. Serum calciu
Am Obstet Gynecol 1977;127:775-8.

10 Marshall RW, Francis RM, Hodgkinson A. Plasma total and ionised calcium albumin and globulin concentrations in pre- and post-menopausal women and

11 Fogh-Andersen N, McNair P, Møller-Petersen J, Madsbad S. Lowered serum ionized calcium in insulin treated diabetics. Scand f Clin Lab Invest 1983;43

12 Graham G, Burrit $M$. Preliminary report: AACC ionized calcium working group on reference intervals [Abstract]. Clin Chem 1983;29:1187.

13 Lazar RS, Deane B, Bowers GN. Free ionized calcium in serum. Increase in the upper reference limit for ambulatory patients and the relationship to con29: 1187 .

(Accepted 6 August 1984) Donnan effect or protein interference in ionised calcium measurements ?

\section{ONE HUNDRED YEARS AGO}

The relationship between sleep, "the cousin of death," and death itself, is probably real as well as apparent. The distance which separates them is great, but there are intermediate connections, grades of dissolution as of development. Among these the similar states of trance and hybernation are worthy of special notice. For sleep and for trance one cause, the exhaustion chiefly of nervous matter, but more or less of every organ and tissue, is assignable. The hysterical stupor is the sleep of nerve centres, worn out with the assault and conflict of stormy reflex action. Healthy sleep is the rest of physical elements wearied with the same strain applied more gradually. Cases have been recorded in which somnolence, continuing for days without cessation, has resembled trance in its duration, while preserving all the ordinary features of natural sleep. Various facts support us in associating the hybernation of animals with the same train of organic or functional changes, as the other unconscious states which we have been considering. It comes like a habit; it has, one may say, annual return, its apparent cause is the oppression of external cold, and the animals it affects are mostly those which, from their bodily structure or habits, are subject to great periodic variations of temperature. Vital tissue is exhausted, and function is in part suspended, probably because the numbness of cold has taken hold upon the radicles of the outer circulation, and of that of the brain-surface which is connected with it by numerous anastomoses. In such a case anaemia would seem to be the cause of the winter sleep, as there is evidence to show that it is also the cause of that temporary starvation of brain which lulls without arresting its action, in the natural repose of each night. We may even regard the lethargy, ended by death, into which man falls when exposed to great cold, as a short and mortal hybernation. The same influence acts upon him as upon the bear or fish, but the power of its shock is greater on his finer and less accustomed senses than on their comparatively coarse organisation. So, likewise, in other regions and forms of life, in the weariness, paralysis, atrophy, and gangrene of limbs, in the leafless hybernation of trees, and in their decay, beginning in the terminal twigs, the same teaching is evident, that vascular nutrition, in its periodic variations, is the parent of activity and of rest, as its absence is of death. It is not, therefore, altogether surprising to

meet with occasional instances in which death is simulated by some deep degree of stupor. The case of George Chilcot, a labourer, living at Bridgewater, which was lately recorded in the daily papers, appears to have been one of this kind. The trance-like state developed quite suddenly, and was mistaken by the relatives for death. Some slight degree of warmth in the apparent corpse induced the clergyman in attendance to refuse burial in spite of the decided wish of the relatives that it should take place. After eight days, the signs of animation were re-established, and the subject of this singular experience slowly recovered. In all such cases, there is an element of mystery; and one cannot always decide how much of this is due to physiological or pathological conditions, or to some external agency. We are not informed of the antecedents in the present instance, and cannot say how much hard work, under-feeding, anxiety, or other causes, may have had to do with the result. The state described, if really one of trance, affords a striking example of the difficulty which sometimes, though very rarely, arises in proving the final point in diagnosis, and a warning that the most trivial sign of vitality should not be overlooked in determining the fact of death. (British Medical fournal 1884;ii :721.)

At a recent meeting of the St. Petersburg Health Committee, some statements were made, according to the Pall Mall Gazette, which throw a sinister light on some of the Russian hospitals and nurses. Professor Botkin, speaking of the large death-rate in the St. Petersburg hospitals, said: "I have come to the conclusion that the patients die mostly from weakness, for, with their daily allowance of thirteen or fourteen copecks, they cannot even buy a pound of beef for broth. In addition to this, the nurses, who are very badly paid, steal the food of the patients whenever they can." Considerable surprise is also sometimes expressed in St. Petersburg society at the rapid growth of wealth among hospital-authorities. This subject, however, Dr. Botkin prudently left untouched. But surely there cannot be many nurses who are capable of starving their patients to death in order to make money! (British Medicalfournal 1884 ;ii:1027.) 